\title{
Water: The Environmental, Technological, and Societal Complexity of a Simple Substance
}

\author{
Janet G. Hering 1 1,2,3 \\ ${ }^{1}$ Eawag, Swiss Federal Institute for Aquatic Science and Technology, Dübendorf, Switzerland \\ ${ }^{2}$ Swiss Federal Institute of Technology (ETH) Zürich, Zürich, Switzerland \\ ${ }^{3}$ Swiss Federal Institute of Technology Lausanne (EPFL), Lausanne, Switzerland
}

This introductory article of the Encyclopedia of Water: Science, Technology, and Society is intended to provide some insights into the many aspects of water and water management that will be addressed more detail in later articles. This article also provides a rationale for integrating across the natural, engineering, and social sciences in framing problems relating to water allocation and use and in identifying solutions for sustainable water management (SWM).

\section{Basics}

Although it is composed of only two elements, water $\left(\mathrm{H}_{2} \mathrm{O}\right)$ is not the simple substance that it might appear to be. Because of its unique chemical and biophysical properties, water plays critical roles at scales ranging from molecular to global $[1,2]$. Water is nearly a "universal solvent" in which ionic salts are highly soluble, polar organic liquids can be fully miscible, and emulsions can be formed with complex biomolecules including proteins and lipids. Water is a predominant constituent of all living organisms, providing structural integrity and solubilizing and transporting chemical substances. The importance of water in biology is illustrated by the variety of adaptations that desert plants have evolved to cope with extreme desiccation and to respond to pulsed moisture inputs [3].

Water has two physical properties that have profound implications at larger scales. The first of these is the density maximum of liquid water at $4{ }^{\circ} \mathrm{C}$, with the familiar consequence that ice floats on water. Thus ice can insulate surface waters, which can remain unfrozen at depth allowing the overwintering of fishes and other aquatic organisms. The second is the high heat of vaporization of water, which results in latent heat transport associated with evaporation of water at low latitudes and its condensation at higher latitudes. Latent heat transfer accounts for approximately $23 \%$ of the incoming solar radiation and links the hydrologic and energy cycles of the planet [1].

Covering nearly three-quarters of the Earth's surface, water is the planet's dominant geographic feature. The distribution of water in the landscape has profoundly influenced patterns of human settlement and migration [4]. Early settlement patterns were shaped by human use of water for water supply (including irrigated agriculture), transport, waste conveyance, and fishing. At the same time, settlement near rivers or in coastal areas increased exposure to the destructive forces of storms, floods, and tsunamis.

Water has enormous cultural, political, and economic significance [5]. These three critical dimensions are addressed in the Valuing Water initiative of the United Nations (UN) High-Level Panel on Water, which explicitly includes nonmonetary values and incorporates cultural contexts [6]. The association of water with cleansing and rebirth, indeed with life itself, is embedded in most if not all of the world's religions as exemplified by baptism in Christianity and the seven sacred rivers of Hinduism. Rivers are also sacred in Aboriginal cultures; respect and reverence for water are eloquently expressed in the Haudenosaunee Thanksgiving Address [7]:

We give thanks to all the waters of the world for quenching our thirst and providing us with strength. Water is life. We know its power in many forms - waterfalls and rain, mists and streams, rivers and oceans. With one mind, we send our greetings and our thanks to the spirit of Water.

The rights of the environment (or nature) to water is established in some national laws and constitutions. The 


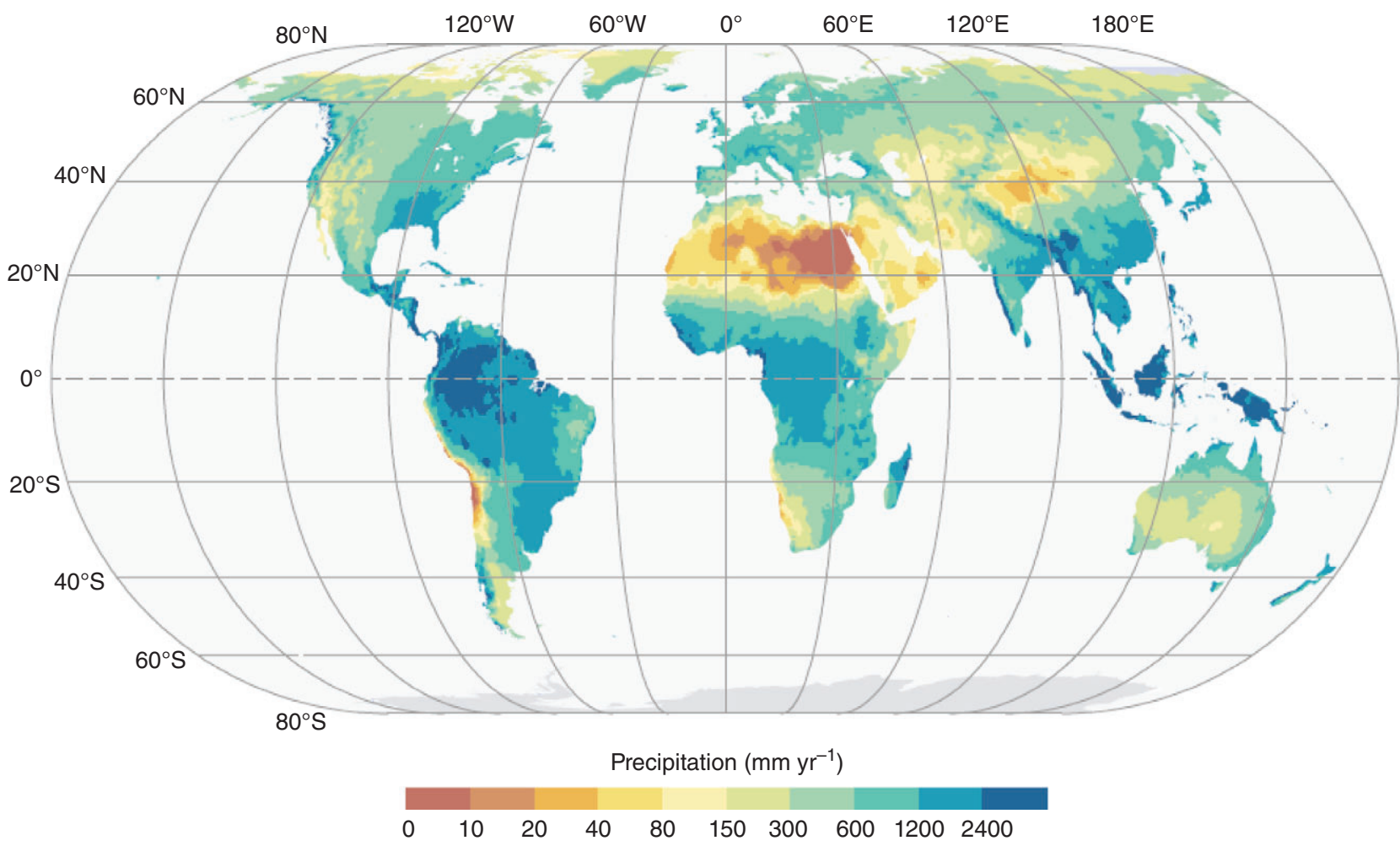

Figure 1 Mean annual precipitation (1981-2010) shown in a projection (Eckert IV) that accurately reflects land surface area. Source: GPCC Full Data Reanalysis Version 6.0 at $0.5^{\circ}$, monthly land-surface precipitation from rain-gauges built on GTS-based and historical data. Map prepared by M. Epprecht, P. Vollmar and A. Weber (Centre for Development and Environment, CDE, University of Bern, Switzerland). This graphic licensed to the public under a Creative Commons Attributions 4.0 license.

South African National Water Act of 1998 requires that environmental protection is accommodated in the allocation of water use rights [8] and the "rights of Nature" are recognized in the constitution of Ecuador, ratified in 2008 [9]. The Ganges and Yamuna Rivers in India and the Whanganui River in New Zealand have the status of persons under the law [10].

Throughout history, the management of water supply and water resources has been a central responsibility of civil society. These responsibilities have ranged from supplying water for consumption, sanitation, firefighting, and irrigation to reclaiming land for settlement and agriculture, protecting fisheries and navigation, mitigating effects of flooding and building infrastructure for storage, conveyance, and hydropower generation. The intensive dependence of human societies on water has resulted in major alterations of water bodies, water courses and the land adjacent to them. For example, it is estimated that over $400000 \mathrm{~km}^{2}$ of wetlands in the continental USA were lost between the beginning of European settlement in the early 1600s and mid-1980s; six states are estimated to have lost $>85 \%$ of their wetlands [11]. It is also estimated that surface water storage globally has been increased by about $305000 \mathrm{~km}^{2}$ as a result of reservoir construction [12].

\section{Variability in Freshwater Availability}

Although available freshwater constitutes only a minute proportion of the total water on the planet, there is still much more renewable freshwater (i.e. precipitation falling on land as a global annual average) that would be needed to support human needs [13]. The spatial variation of annual average precipitation, however, ranges from $<100$ to $>2000 \mathrm{~mm}$. In Figure 1, this variability is shown on a map that is faithful to land surface area (unlike the more commonly-used Mercator projection). The Eckert projection in Figure 1 emphasizes the huge landmass of the African continent, as well as the extreme variability in the annual average precipitation that it receives. Even in regions where the local precipitation is not dramatically different from the world average, strong temporal variability in rainfall can lead to extended dry periods. Rivers naturally supply lowland areas in catchments with water derived from precipitation or from the melting of snow and ice in upland areas. Withdrawal 


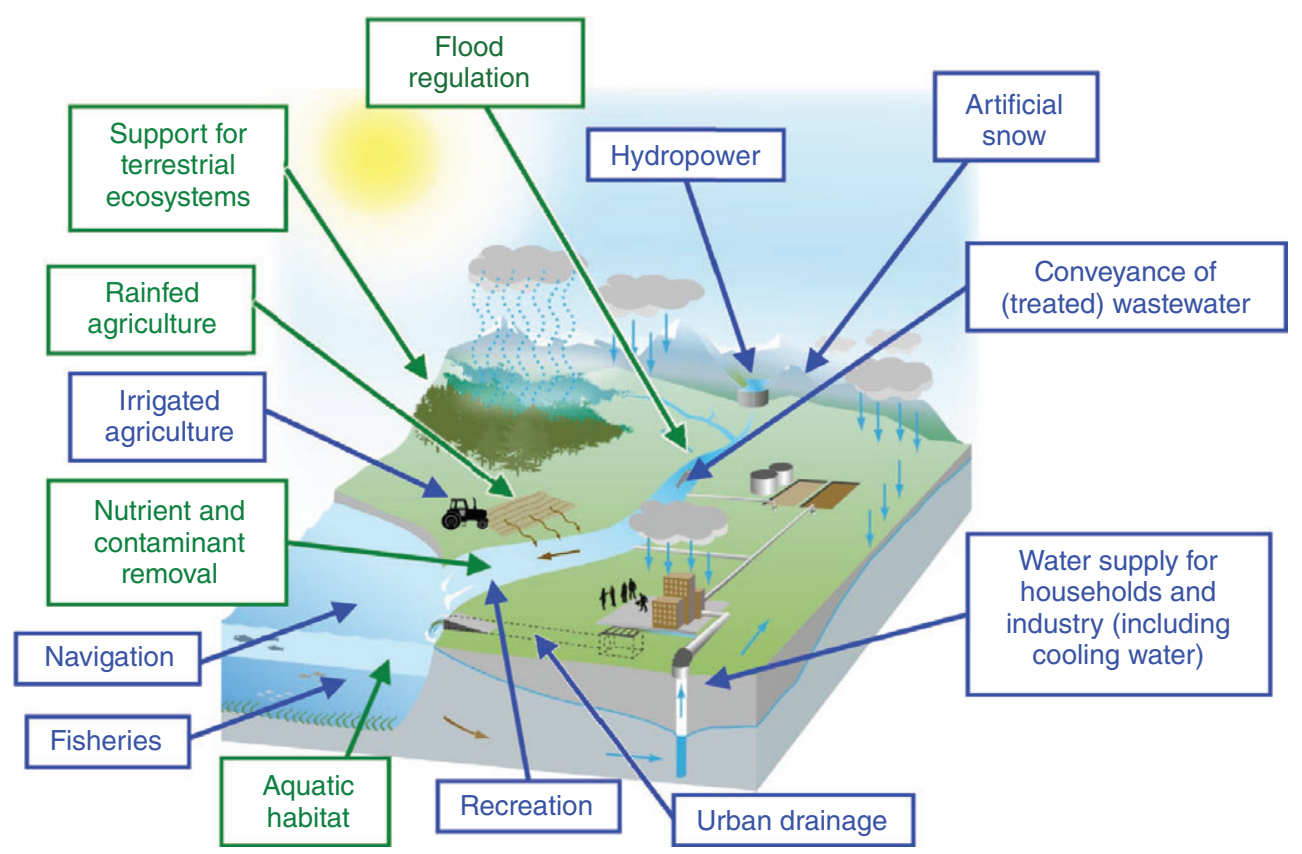

Figure 2 Direct human uses (blue) and indirect ecosystem services (green) provided by the water environment. This graphic is licensed to the public under a Creative Commons Attributions 4.0 license.

from lakes or groundwater can also offset deficiencies in water availability associated with variability in precipitation. Both natural conveyance and storage, as the end results of processes that occurred over geologic time, are spatially differentiated.

The focus on storage and conveyance throughout history reflects the vulnerability of societies to the spatial and temporal variability of precipitation and of natural storage and conveyance. Artificial storage (reservoirs) and conveyance (aqueducts) date back to antiquity in Egypt, Persia, and the Roman Empire [14]. The reduction of societal risks by water infrastructure [15-17] motivated past investments made in industrialized countries and supports arguments for increased infrastructure investment in low- and middle-income countries (LMICs) [5, 18]. The medium term needs for investment for water infrastructure (which can be exacerbated by a culture of poor maintenance) are estimated at more than $\$ 1.2$ trillion annually [19].

\section{Conflicting Uses and Competing Demands}

The societal benefits of infrastructure projects have also been accompanied by harm, most often to the environment but also to people, especially those who have been relocated [20]. Many of the environmental impacts of past infrastructure projects (e.g. loss of biodiversity) are no longer considered acceptable in industrialized countries, which have consequently invested in restoration [21] and expressed objections to infrastructure projects in LMICs [5]. These objections are reinforced by concerns that climate change introduces unacceptable levels of uncertainty into infrastructure planning and might compromise the expected benefits of infrastructure investment.

Direct human uses of water often involve the extraction or diversion of (blue) water from the environment. In addition, societies are dependent on ecosystem services provided by the aquatic environment, including the support of terrestrial ecosystems and rainfed agriculture (green water). These uses and services are illustrated schematically in Figure 2, which highlights that blue and green water are intimately linked and that good ecosystem function is vital for both. The use of water for dilution or transport of waste is sometimes referred to as gray water [22], though this can be difficult to quantify since it depends on the standards applied for acceptable water quality [23].

It is undeniable that direct human uses of water can be incompatible with each other or with the maintenance of ecosystem function and the continued provision of ecosystem services. Perhaps the most dramatic example of such conflicts resulted from the diversion of flows to the Aral Sea for cotton irrigation [24]. Over four decades, the volume of the Aral Sea decreased by $>80 \%$ and nearly all its native species were extirpated. 
Fundamentals of Water, Chemistry, Particles, and Ecology

Table 1 Dichotomies in perception and implementation that impede sustainable water management.

\begin{tabular}{|c|c|c|}
\hline Concepts taken to be in opposition & & Exemplary linking issues \\
\hline Agricultural use & Urban use & $\begin{array}{l}\text { - Agricultural return flows } \\
\text { - Use of reclaimed water/treated wastewater in agriculture }\end{array}$ \\
\hline Blue water & Green water & - Approximately $80 \%$ of agricultural production is rainfed \\
\hline Engineered system & Natural system & $\begin{array}{l}\text { - Partially engineered systems (e.g. managed aquifer recharge, } \\
\text { riverbank filtration) }\end{array}$ \\
\hline Expert & Stakeholder & $\begin{array}{l}\text { - Broader (e.g. political or value-driven) interests of technical } \\
\text { experts } \\
\text { - Technical (but also experiential) expertise of members of } \\
\text { stakeholder groups }\end{array}$ \\
\hline Groundwater & Surface water & $\begin{array}{l}\text { - Conjunctive use } \\
\text { - Linked recharge and withdrawal pathways }\end{array}$ \\
\hline Human allocation & Ecosystem allocation & - Societal benefits from ecosystem services \\
\hline Water quality & Water quantity & $\begin{array}{l}\text { - Degradation of groundwater quality due to over-pumping } \\
\text { (seawater intrusion) }\end{array}$ \\
\hline
\end{tabular}

The management of transboundary waters must explicitly address the competing interests of different national (or sometimes sub-national) parties. Diversion of surface flows (or groundwater) by upstream (or upgradient) users can have obvious negative impacts on downstream (or downgradient) users. Despite such conflicting interests, transboundary water resources have generally inspired more cooperation than open conflict [5]. The United Nations Convention of the Protection and Use of Transboundary Watercourses and International Lakes was adopted in 1992 by European countries and was amended in 2003 to allow adoption by all UN member countries [25]. The Water Convention, which addresses water pollution, ecologically sound water management, equitable use of transboundary waters, and ecosystem conservation and restoration serves as the basis for the concept of "hydro-diplomacy" or "blue peace" [26, 27].

An additional source of international competition arises from the transfer of virtual water in international trade (especially of food). Nearly $70 \%$ of the use of blue water is associated with irrigated agriculture and some countries (particularly in the Middle East) rely on food importation to offset deficiencies in local water availability [28]. Export-oriented agricultural production may, however, come at the expense of land use for local needs. Some water-sufficient countries (e.g. Switzerland) are heavily dependent on imported food [29] though the biggest environmental impacts abroad are, for Switzerland, associated with imports of cocoa, coffee, and palm oil for food processing [30].

Further development of large-scale water infrastructure (i.e. for storage and conveyance) in LMICs must balance needs for improved water security with impacts on ecosystems, particularly in the context of climate change. It is, however, neither ethical nor realistic to expect that LMICs will forego the improvement in water (and associated energy) security that infrastructure can provide and from which societies in industrialized countries have long benefited [5, 18]. A substantial expansion in hydropower production is anticipated from the planned or current construction of over 3700 major dams having capacities of at least $1 \mathrm{MW}$, most of which will be sited in LMICs [31].

The multiple uses of water and multiple demands to which aquatic ecosystems are subject clearly pose challenges. This has led to polarization that tends to obscure possible common interests and/or opportunities for collaborative solutions. Often such polarization is embedded in laws, regulations, and administrative structures, which obscure the linkages between uses of waters in different sectors [32]. Some perceived dichotomies that arise in the management of water supply, water resources, and aquatic ecosystems are listed in Table 1. Some of these perceived dichotomies (e.g. between surface and groundwater) clearly defy physical reality and all of them stand in the way of an integrated approach to SWM.

\section{Sustainable Water Management and the Sustainable Development Goals}

The need to improve the sustainability of water management is particularly pressing in the context of increasing urbanization in LMICs [33]. Conventional models of urban water management, which reflect the climatic conditions of Western Europe and North America, are generally less appropriate for locations subject to the highest urbanization pressures. Municipalities and local 
governments have been at the forefront of promoting and implementing more sustainable approaches to water management, particularly by integrating issues of resilience to natural hazards and of energy conservation [33, 34]. There is also an untapped potential in cities to implement concepts of the circular economy by recovering water, energy and nutrients from sewage and solid waste [35].

The Sustainable Development Goals (specifically SDG 6) address the need to ensure access to safe water and sanitation and sound management of freshwater ecosystems [36]. Critical issues include the pressing needs to increase access to safely managed sanitation (target 6.2) and the proportion of wastewater that is safely treated (indicator 6.3.1 under target 6.3). Target 6.2 would have clear spin-off benefits in supporting other SDGs, particularly those relating to reducing poverty (SDG 1) and death from preventable diseases (SDG 3), which are often water-borne or related to poor hygiene practices [37]. Even though target 6.3 is perceived as posing a potential conflict with SDGs related to health improvement and poverty reduction [37], this is certainly not the case for indicator 6.3.1. The clear benefits for both human health and the environment that increasing the proportion of safely treated wastewater would bring could provide a basis for prioritizing measures to achieve target 6.3 [38].

\subsection{The Issue of Scale}

The SDGs represent a supranational agreement that devolves responsibilities (e.g. for agenda-setting, monitoring, implementation, and reporting) to nations. Yet the authority for such activities often resides at subnational levels. Integrated water resource management (IWRM) is often posited as the remedy for such fragmentation, which compromises the ability to address problems that transcend local jurisdictions $[39,40]$. The emphasis on integration can, however, impose significant transaction costs [32, 41, 42] and may even hinder the implementation of appropriate solutions on local scales due to a lack of capacity and/or governance structures required for watershed-based, integrated solutions [4, 43]. Such issues suggest that it should be an important part of the analysis of problems relating to SWM to consider the scale(s) on which change can be effected and solutions can be implemented and that nested, tiered, or polycentric frameworks may be useful for both analysis and implementation [44-46].

Participation is also invoked as a means to increase the legitimacy and eventual uptake of SWM strategies [47]. Designing effective participation processes requires not only careful attention to the appropriate scale but also tools to facilitate and support participation $[39,48]$ and respect for different types of knowledge, including local and vernacular knowledge [49].

\subsection{Accessing and Using Knowledge for Sustainable Water Management}

Rapid advances in information technology constitute a megatrend that has the potential to increase access to knowledge relevant to SWM, improving both ease of use and reliability. Ideally, responsible curation would ensure the quality of information and appropriate attribution to original sources and also avoid (or at least clearly identify) conflicts of interest.

Significant efforts have been made to establish databases relevant to SWM. Information on access to improved water and sanitation, collected for monitoring progress toward the Millennium Development Goals, has been expanded by the WHO-UNICEF Joint Monitoring Programme to address safely managed water supply and sanitation in all countries (industrialized as well as LMICs) that adopted the SDGs [50]. The UN High-Level Panel on Water has launched a Water Data Initiative to improve access to observations, processed data and model outputs [51]. There are already a plethora of websites offering access to water data [52], with, unfortunately, minimal cross-referencing among them.

In addition to water data, per se, there is an enormous amount of knowledge that is relevant to SWM. The sheer volume of this knowledge creates an information overload that can itself constitute a barrier to the effective uptake of knowledge [53]. Knowledge produced in the context of academic research often requires brokering to be usable [54]. Even knowledge that was co-produced so as to be usable in a given context [55] may not be easily generalized or transferred to other contexts. There is a pressing need to manage knowledge relevant to SWM as a public good rather than a private asset [56]. A next generation of knowledge platforms [57] is needed to move "from data to information to knowledge and, ultimately, to action for urban sustainability and human well-being" [58].

\subsection{Fostering Cooperation and Collaboration for Sustainable Water Management}

Given the scope of both activities and challenges relating to SWM, cooperation, and collaboration will be essential to achieving SDG 6. Usable knowledge applicable to SWM is most likely to be generated through coproduction in which actors with different expertise, backgrounds, experience, and responsibility cooperate to address a problem of common interest [55]. Knowledge from research (in the natural, social, and engineering 
Table 2 Examples of initiatives and/or boundary organizations promoting sustainable (fresh)water management. ${ }^{\text {a) }}$

\begin{tabular}{|c|c|}
\hline Name (organization) & Website \\
\hline 100 Resilient Cities & http://www.100resilientcities.org \\
\hline Canadian Freshwater Alliance & http://www.freshwateralliance.ca \\
\hline Cooperative Research Centre for Water Sensitive Cities & https://watersensitivecities.org.au \\
\hline European Water Partnership & http://www.ewp.eu \\
\hline Freshwater Information Platform & http://www.freshwaterplatform.eu \\
\hline Gender and Water Alliance & http://genderandwater.org/en \\
\hline Global Water Operators' Partnerships Alliance & https://wateractionhub.org/gwopa \\
\hline Global Water Alliance & http://www.globalwateralliance.net \\
\hline Global Water Partnership & http://www.gwp.org \\
\hline International WaterCentre & http://www.watercentre.org/about \\
\hline International Water Management Institute & http://www.iwmi.cgiar.org \\
\hline Millennium Water Alliance & http://mwawater.org \\
\hline National Drinking Water Alliance & http://www.drinkingwateralliance.org \\
\hline Pacific Institute & http://pacinst.org \\
\hline Programme Solidarité-Eau & http://www.pseau.org/en \\
\hline Sustainable Cities Institute (National League of Cities) & http://www.sustainablecitiesinstitute.org \\
\hline Sustainable Sanitation Alliance & http://www.susana.org/en \\
\hline UN Water & http://www.unwater.org \\
\hline Urban Water Blueprint (Nature Conservancy) & http://water.nature.org/waterblueprint/\#/intro=true \\
\hline US Water Alliance & http://uswateralliance.org \\
\hline Water and Sanitation (United Cities and Local Governments) & https://www.uclg.org/en/issues/water-and-sanitation \\
\hline Water Footprint Network & http://waterfootprint.org/en \\
\hline Water Future & http://water-future.org \\
\hline Water Scarce Cities Initiative (World Bank) & http://www.worldbank.org/waterscarcecities \\
\hline Water SMART (US Bureau of Reclamation) & https://www.usbr.gov/watersmart \\
\hline Water-Wise Cities (International Water Association) & http://www.iwa-network.org/projects/water-wise-cities \\
\hline World Water Council & http://www.worldwatercouncil.org/index.php?id=1 \\
\hline
\end{tabular}

a) Websites listed alphabetically. This list is not intended to be comprehensive but rather to provide representative examples of relevant websites hosted by both governmental and nongovernmental organizations. Initiatives and/or boundary organizations with a focus on marine systems are excluded.

sciences) will need to be combined with technical expertise gained in practice by water professionals as well as with the knowledge and expectations of organizations (and even individuals) who depend on water systems. Although some integration of approaches and understanding may develop through such cooperation, this should not be promoted at the cost of losing valuable insights that derive from different perspectives [59]. Such collaborations must respect the validity of different criteria for the justification of knowledge (i.e. considered as "justifiable belief") [47]. Tools for decision support $[60,61]$ and collaborative or participatory modeling [39, 48] can be a valuable aid to collaboration.

There is a huge range in conditions (i.e. from climate to existing infrastructure to individual and institutional capacities) that define the contexts in which SWM practices must be implemented [33]. These varying contexts make it impossible that any single technology or approach will emerge as a universally applicable "silver bullet". Nonetheless, adaptation of technologies or approaches of proven efficacy to local contexts would likely be a much better use of resources than de novo development or (worse yet) reinvention. A robust and open evidence base is needed to support such adaptation. Various initiatives have been established to address water issues either as a primary focus or in the context of sustainability and/or resilience. A noncomprehensive list of such initiatives and/or boundary organizations is provided in Table 2 . Although a diversity of organizations and initiatives can be valuable, their proliferation is almost certain to result in considerable duplication of effort. Greater benefit might result from 
cross-referencing among such initiatives and/or boundary organizations to help leverage their activities. It would even seem feasible to design a portal for knowledge users that would provide access to information beyond that available on individual websites curated by trusted organizations yet more constrained than the comprehensive results of highly variable quality returned by general web searches (e.g. Google) [57].

\section{Water and Sustainable Water Management at the Nexus of Science, Technology, and Society}

Management of water supply, water resources, and aquatic ecosystems has often been quite technocratic and sectoral. It has also been heavily influenced by past practices and infrastructure investments as well as legal and regulatory frameworks that do not sufficiently accommodate future needs or even adequately reflect some current situations and constraints. For example, the historical extent and function of aquatic ecosystems can provide valuable insight for future ecosystem management, but

\section{References}

1 Berner, E.K. and Berner, R.A. (2012). Global Environment: Water, Air, and Geochemical Cycles. Princeton, NJ, USA: Princeton University Press.

2 Water (CID 962). https://pubchem.ncbi.nlm.nih .gov/compound/water\#section=Top (accessed 17 September 2017).

3 Schwinning, S. and Sala, O.E. (2004). Oecologia 141: 211-220. doi: 10.1007/s00442-004-1520-8.

4 Hering, J.G., Sedlak, D.L., Tortajada, C. et al. (2015). Science 349: 479-480. doi: 10.1126/science.aac5902.

5 Priscoli, J.D. (2012). Water Policy 14: 21-40. doi: 10.2166/wp.2012.002.

6 HLPW (2017). Roadmap of the Valuing Water Initiative. UN High Level Panel on Water, 7 pp. https:// sustainabledevelopment.un.org/content/documents/ 15595Road_Map_Valuing_Water_Initiative_vs_1.1_ March_8th_updated_May_19th_2017.pdf.

7 Haudenosaunee Thanksgiving Address - 3. The Waters. https://danceforallpeople.com/ haudenosaunee-thanksgiving-address/haudenosauneethanksgiving-address-3 (accessed 19 August 2017).

8 Pienaar, G.J. and van der Schyff, E. (2007). Law, Environ. Dev. J. 3: 179-194.

9 Ecuador Adopts Rights of Nature in Constitution. http://therightsofnature.org/ecuador-rights (accessed 2 September 2017). cannot serve as the model for restoration efforts because of the extensive alteration of these ecosystems. The future management of aquatic ecosystems, as well as of infrastructure systems, will require that direct human needs are balanced with ecosystem function.

In the future (and even in today's water-stressed regions), the increasing complexity of water infrastructure systems, increasing inter-linkages among the water sector and other sectors (e.g. energy and agriculture), and increasing pressures and demands on aquatic ecosystems call for more integrated and participatory approaches [43]. Fully engineered "gray" infrastructure will still be necessary [18] but could be complemented with partially engineered "green" infrastructure [62]. As water supply and wastewater treatment systems become more decentralized and integrated into the circular economy, greater flexibility on the part of system managers, and increased participation by system users will be needed [63]. Concerted efforts are needed to fulfill the "great potential to complement sustainable development projects ... with robust knowledge, tools and scientific methods" [64]. These issues will be addressed in detail in later articles in this encyclopedia.

10 O'Donnell, E. and Talbot-Jones, J. (2017). Three rivers are now legally people - but that's just the start of looking after them. The Conversation, http:// theconversation.com/three-rivers-are-now-legallypeople-but-thats-just-the-start-of-looking-after-them74983 (accessed 2 September 2017).

11 History of Wetlands in the Conterminous United States, https://water.usgs.gov/nwsum/WSP2425/ history.html (accessed 1 September 2017).

12 Lehner, B., Liermann, C.R., Revenga, C. et al. (2011). Front. Ecol. Environ. 9: 494-502. doi: 10.1890/100125.

13 Oelkers, E.H., Hering, J.G., and Zhu, C. (2011). Elements 7: 157-162. doi: 10.2113/gselements.7.3.157.

14 Mays, L.W. (ed.) (2010). Ancient Water Technologies, 280. Dordrecht: Springer.

15 Padowski, J.C. and Gorelick, S.M. (2014). Environ. Res. Lett. 9: doi: 10.1088/1748-9326/9/10/104004.

16 Padowski, J.C., Gorelick, S.M., Thompson, B.H. et al. (2015). Environ. Res. Lett. 10: doi: 10.1088/1748-9326/10/10/104014.

17 Voeroesmarty, C.J., McIntyre, P.B., Gessner, M.O. et al. (2010). Nature 467: 555-561. doi: 10.1038/nature09440.

18 Muller, M., Biswas, A., Martin-Hurtado, R., and Tortajada, C. (2015). Science 349: 585-586. doi: 10.1126/science.aac7606. 
19 World Bank (2011). Rebalancing, Growth, and Development: An Interconnected Agenda. Washington, D.C.: The World Bank, 13 pp. http://go.worldbank.org/ MB562QV3S0.

20 Agnew, C. and Woodhouse, P. (2011). Water Resources and Development. London: Routledge.

21 Anisfeld, S.C. (2010). Water Resources. Washington, D.C.: Island Press.

22 Hoekstra, A.Y., Chapagain, A.K., Aldaya, M.M., and Mekonnen, M.M. (2011). The Water Footprint Assessment Manual: Setting the Global Standard, 203. London, UK: Earthscan.

23 Liu, W., Antonelli, M., Liu, X., and Yang, H. (2017). J. Clean. Prod. 147: 1-9. doi: 10.1016/j.jclepro.2017.01.072.

24 Stone, R. (1999). Science 284: 30-33. doi: 10.1126/science.284.5411.30.

25 Water Convention, http://www.unece.org/env/water (accessed 6 September 2017).

26 Hydro-diplomacy: sharing water across borders. https://www.iucn.org/content/hydro-diplomacysharing-water-across-borders (accessed 20 September 2017).

27 Global High-Level Panel on Water and Peace, $A$ Matter of Survival. 2017. Geneva: Geneva Water Hub; 104 pp. https://www.genevawaterhub.org/sites/ default/files/atoms/files/report_of_the_ghlpwp_final_ withcover_20171220.pdf

28 Yang, H., Reichert, P., Abbaspour, K.C., and Zehnder, A.J.B. (2003). Environ. Sci. Technol. 37: 3048-3054. doi: 10.1021/es0263689.

29 Engel, K. and Kraljevic, A. (2016). The Imported Risk: Switzerland's Water Risk in Times of Globalisation. Zurich: WWF Switzerland, 91 pp. https://assets.wwf .ch/downloads/study_imported_risk.pdf.

30 Chaudhary, A., Pfister, S., and Hellweg, S. (2016). Environ. Sci. Technol. 50: 3928-3936. doi: 10.1021/acs.est.5b06153.

31 Zarfl, C., Lumsdon, A.E., Berlekamp, J. et al. (2015). Aquat. Sci. 77: 161-170. doi: 10.1007/s00027-014-0377-0.

32 Hering, J.G. and Ingold, K.M. (2012). Science 336: 1234-1235. doi: 10.1126/science.1218230.

33 Hering, J.G. and Vairavamoorthy, K. (2018). Assessing Water Megatrends (ed. A.K. Biswas and C. Tortajada), 61-75. Berlin, Germany: Springer.

34 Water 101: Sustainability Principles. http://www .sustainablecitiesinstitute.org/topics/water-andgreen-infrastructure/water-101/water-sustainabilityprinciples (accessed 19 August 2017).

35 Larsen, T.A., Hoffmann, S., Luthi, C. et al. (2016). Science 352: 928-933. doi: 10.1126/science.aad8641.
36 Sustainable Development Goal 6. https:// sustainabledevelopment.un.org/sdg6 (accessed 6 September 2017).

37 UN-Water (2016). Water and Sanitation Interlinkages Across the 2030 Agenda for Sustainable Development. Geneva: UN-Water, 47 pp. http://www.unwater.org/ publications/water-sanitation-interlinkages-across2030-agenda-sustainable-development/.

38 Hering, J.G. (2017). Sustainability 9. doi: 10.3390/su9091572.

39 Basco-Carrera, L., Warren, A., van Beek, E. et al. (2017). Environ. Model Softw. 91: 95-110. doi: 10.1016/j.envsoft.2017.01.014.

40 von Korff, Y., Daniell, K.A., Moellenkamp, S. et al. (2012). Ecol. Soc. 17: doi: 10.5751/ES-04733-170130.

41 Hering, J.G., Hoehn, E., Klinke, A. et al. (2012). Environ. Sci. Technol. 46: 112-118. doi: 10.1021/es202189s.

42 Jacobs, K., Lebel, L., Buizer, J. et al. (2016). Proc. Natl. Acad. Sci. U. S. A. 113: 4591-4596. doi: 10.1073/pnas.0813125107..

43 Islam, S. and Repella, A.C. (2015). Journal of Contemporary Water Research E Education 155: 1-10. doi: 10.1111/j.1936-704X.2015.03190.x.

44 Ostrom, E. (2007). Proc. Natl. Acad. Sci. U. S. A. 104: 15181-15187. doi: 10.1073/pnas.0702288104..

45 Ostrom, E. (2010). Global Environ. Change-Human Policy Dimens. 20: 550-557. doi: 10.1016/j.gloenvcha.2010.07.004.

46 Marshall, G. (2007). Int. J. Commons 2: 75-97. doi: 10.18352/ijc.50.

47 van Kerkhoff, L. and Lebel, L. (2006). Аnnu. Rev. Environ. Resour. 445-477.

48 GWP, Collaborative Modelling - Engaging Stakeholders in Solving Complex Problems of Water Management. 2017. Stockholm: Global Water Partnership; pp. http://www.gwp.org/globalassets/global/ toolbox/publications/perspective-papers/collaborativemodelling_perspectives_paper.pdf

49 Simpson, H., de Löe, R., and Andrey, J. (2015). Water Alternatives 8: 352-372.

50 WHO; UNICEF, Progress on Drinking Water, Sanitation and Hygiene: 2017 Update and SDG Baselines. 2017. Geneva: World Health Organization and the United Nations Children's Fund; 109 pp. https:// washdata.org/reports

51 (2017. UN High Level Panel on Water). World Water Data Initiatve Roadmap. HLPW, 16 pp. https:// sustainabledevelopment.un.org/content/documents/ 13327HLPW_WWDI_Roadmap.pdf.

52 Hering, J.G. (2017). Water Data Portals : An Annotated List (Versions 3). Open Science Framework, 3 pp. https://osf.io/8mn3q/. 
53 Hering, J.G., Nunnemacher, L., and von Waldow, H. (2018). Handbook of Knowledge Management for Sustainable Water Systems (ed. M. Russ), 13-33. New York, NY, USA: Wiley.

54 Hering, J.G. (2016). Sustain. Sci. 11: 363-369. doi: 10.1007/s11625-015-0314-8.

55 Clark, W.C., van Kerkhoff, L., Lebel, L., and Gallopin, G.C. (2016). Proc. Natl. Acad. Sci. U. S. A. 113: 4570-4578. doi: 10.1073/pnas.1601266113..

56 van Kerkhoff, L. (2013). Challenges in Sustain. 1: 82-93. doi: 10.12924/cis2013.01020082.

57 Hering, J.G.; von Waldow, H. (2017). Concept Note: Call for Management of Knowledge Relating to Freshwater and Sustainable Knowledge Management as a Public Good (version 2). https://osf.io/28rhn/

58 Ramaswami, A., Russell, A.G., Culligan, P.J. et al. (2016). Science 352: 940-943. doi: 10.1126/science.aaf7160.
59 Alroe, H.F. and Noe, E. (2014). Constructivist Foundations, vol. 10, 65-76.

60 McIntosh, B.S., Ascough, J.C. II, Twery, M. et al. (2011). Environ. Model Softw. 26: 1389-1402. doi: 10.1016/j.envsoft.2011.09.009.

61 Reichert, P., Langhans, S.D., Lienert, J., and Schuwirth, N. (2015). J. Environ. Manag. 154: 316-332. doi: 10.1016/j.jenvman.2015.01.053.

62 Palmer, M.A., Liu, J., Matthews, J.H. et al. (2015). Science 349: 584-585. doi: 10.1126/science.aac7778.

63 Hering, J.G., Waite, T.D., Luthy, R.G. et al. (2013). Environ. Sci. Technol. 47: 10721-10726. doi: 10.1021/es4007096.

64 Water and Sustainable Development: From Vision to Action - Means and Tools for Implementation and Role of Different Actors. http://www.un.org/ waterforlifedecade/pdf/WaterandSD_Vision_to_ Action-2.pdf (accessed 6 November 2015). 